\title{
Control of Glyphosate-Resistant Marestail in Identity-Preserved or Glyphosate-Resistant and Glyphosate/Dicamba-Resistant Soybean with Preplant Herbicides
}

\author{
Nader Soltani*, Christy Shropshire, Peter H. Sikkema \\ University of Guelph Ridgetown Campus, Ridgetown, Ontario, Canada \\ Email: *soltanin@uoguelph.ca
}

How to cite this paper: Soltani, N., Shropshire, C. and Sikkema, P.H. (2020) Control of Glyphosate-Resistant Marestail in Identity-Preserved or Glyphosate-Resistant and Glyphosate/Dicamba-Resistant Soybean with Preplant Herbicides. American Journal of Plant Sciences, 11, 851-860.

https://doi.org/10.4236/ajps.2020.116061

Received: May 11, 2019

Accepted: June 25, 2020

Published: June 28, 2020

Copyright $\odot 2020$ by author(s) and Scientific Research Publishing Inc. This work is licensed under the Creative Commons Attribution International License (CC BY 4.0).

http://creativecommons.org/licenses/by/4.0/

\begin{abstract}
Two studies, each consisting of six field experiments were conducted in growers' fields in 2018 and 2019 to determine the optimal herbicide tankmixes, applied preplant (PP) for the control of glyphosate-resistant (GR) marestail in 1) identity-preserved and glyphosate-resistant soybean (Study 1) and, 2) glyphosate/dicamba-resistant soybean (Study 2). There was no significant injury in soybean with the PP herbicides evaluated in both studies. In Study 1 , at 8 weeks after treatment (WAA), glyphosate + saflufenacil, glyphosate + 2,4-D ester, glyphosate + pyraflufen/2,4-D, glyphosate,+ 4 -D choline or glyphosate + halauxifen-methyl, applied PP, controlled GR marestail 93\%, $58 \%, 60 \%, 67 \%$ and $71 \%$, respectively. The addition of metribuzin to the tankmixes of glyphosate + saflufenacil, 2,4-D ester and pyraflufen/2,4-D increased the control to $98 \%, 91 \%$ and $95 \%$, respectively. The addition of metribuzin + chlorimuron-ethyl to 2,4-D choline/glyphosate and glyphosate + halauxifen-methyl increased the control to $94 \%$ and $93 \%$, respectively. In Study 2, at 8 WAA, glyphosate/dicamba, applied PP, controlled GR marestail $89 \%$ in glyphosate/dicamba-resistant soybean. The addition of metribuzin or saflufenacil to glyphosate/dicamba controlled GR marestail $86 \%$ and $97 \%$, respectively. At 8 WAA, $S$-metolachlor/dicamba controlled GR marestail $83 \%$. The addition of metribuzin or saflufenacil to the above premix controlled GR marestail $87 \%$ and $97 \%$, respectively. Density and biomass reductions were similar to visible control. GR marestail interference reduced soybean yield 60\% and 53\% in Study 1 and 2, respectively. Reduced GR marestail interference with all the herbicide treatments evaluated in both studies resulted in soybean yield that was similar to the weed-free control.
\end{abstract}




\section{Keywords}

Biomass, Crop Injury, Density, Glyphosate, Herbicide Tankmixture, Metribuzin, Saflufenacil, Yield

\section{Introduction}

Marestail (Conyza canadensis L. Cronq.) is a highly competitive winter or summer annual weed from the Asteraceae family that is native to North America [1]. Globally, marestail is most abundant in north temperate zones which suggest that it has few specialized climatic requirements [1]. In Canada, marestail is found in all provinces except in Newfoundland [1]. In the past, marestail was found mainly in roadsides, orchards and recently abandoned fields. More recently it has become abundant in reduced-, strip-, and no-till crop production systems [1] [2].

Marestail is well adapted to coarse-textured, well-drained soils and is frequently found on sandy knolls [1]. Marestail begins flowering in late July, primarily through self pollination, although up to $4 \%$ out crossing is possible [3] [4]. Seeds reach maturity by late August to mid-September [5]. Each marestail plant can produce up to a quarter million seeds; the number of seeds is proportional to its height [1] [6]. Marestail seed disperses primarily by wind although it can be dispersed by moving water as well [7] [8]. Marestail has two primary emergence periods, in the fall (August to October) and spring (April to May) [3] [5]. Marestail is a very competitive weed and depending on the density and time of emergence can cause up to a 93\% soybean yield reduction [9] [10] [11].

Glyphosate-resistant (GR) marestail was first confirmed in Ontario from seed collected in 2010 [11]. Glyphosate-resistant marestail is now present in 30 counties in Ontario from Essex county adjacent to the Michigan border to Glengarry county adjacent to the Quebec border [9] [10]. The challenge of managing GR marestail has been exacerbated in recent years with the evolution of multiple-resistant biotypes [11]. In Ontario, the average yield losses due to marestail competitiveness in soybean have been estimated to be $65 \%$ [12].

Earlier studies have reported variable GR marestail control in soybean in Ontario with most two-way herbicide tankmixes [9] [10]. Growers need consistent, full-season control of glyphosate-resistant marestail in soybean to maintain yield and be competitive in the global marketplace. In identity-preserved and glyphosate-resistant soybean, postemergence (POST) herbicide options generally do not adequately control GR marestail, in part because this troublesome weed can emerge throughout the growing season [9] [10]. Preplant (PP) herbicide mixtures that have burndown and extended residual activity are the preferred options for the control of GR marestail in GR soybean [9] [10]. New herbicides or herbicide combinations need to be identified that provide more consistent control of this problematic weed in Ontario. 
In identity-preserved and glyphosate-resistant soybean, saflufenacil, 2,4-D ester, pyraflufen/2,4-D, 2,4-D choline/glyphosate, and halauxifen-methyl applied PP alone or in combination with metribuzin have the potential to provide consistent control of GR marestail. In glyphosate/dicamba-resistant soybean, glyphosate/dicamba or s-metolachlor/dicamba form the foundation for the control of GR marestail, however control is variable. Three-way tank mixtures with either saflufenacil or metribuzin need to be evaluated. To our knowledge, no study has cumulatively compared the efficacy of these herbicide tankmixes for the control of GR marestail in soybean under Ontario environmental conditions.

The aim of this research was to identify herbicide tankmixes that provide consistent control of GR marestail in identity preserved or glyphosate-resistant soybean and glyphosate/dicamba-resistant soybean under Ontario growing conditions

\section{Materials and Methods}

Two studies, each consisting of six field experiments were conducted in growers' fields with heavy infestations of GR marestail in 2018 and 2019 (3 in each year for each study) to evaluate the control of GR marestail in identity-preserved or glyphosate-resistant (Study 1) and glyphosate/dicamba-resistant (Study 2) soybean.

Experiments were arranged in a randomized complete block design with 4 replications. Treatments for Study 1 and 2 are presented in Table 1 or Table 2, respectively. Plots were 2.25 wide ( 3 soybean rows spaced $75 \mathrm{~cm}$ apart) by $8 \mathrm{~m}$ in length with a $2 \mathrm{~m}$ walkway between blocks. Soybean was seeded with a three-row no-till planter at approximately 400,000 seeds per ha- ${ }^{-1}$ to a depth of $4 \mathrm{~cm}$.

All herbicide treatments were applied PP in spring, when the marestail plants were approximately $10 \mathrm{~cm}$ in diameter/height using a $\mathrm{CO}_{2}$ pressurized backpack sprayer equipped with a handheld $1.5 \mathrm{~m}$ spray boom, with four ULD120-02 (Pentair, New Brighton, MN, USA) nozzles spaced $50 \mathrm{~cm}$ apart that produced a spray width of $2.0 \mathrm{~m}$. The sprayer was calibrated to deliver $200 \mathrm{~L} \cdot \mathrm{ha}^{-1}$ of spray solution at $240 \mathrm{kPa}$.

Evaluation of visible crop injury and weed control occurred at 4 and 8 weeks after the herbicide application (WAA). These parameters were evaluated on a percent scale and crop injury/weed control in each plot received a rating between 0 and 100, where 0 represents no injury or weed control and 100 represents complete death of the soybean or weed species. GR marestail density and biomass (aboveground dry weight) were determined 8 WAA by counting the number of marestail plants (density) and cutting the plants within two randomly placed $0.25 \mathrm{~m}^{-2}$ quadrats per plot. Biomass was determined by harvesting the aboveground section of GR marestail plants within each quadrat and drying them in a paper bag at $60 \mathrm{C}$ in a kiln for a minimum of 48 hours. Soybean yield was measured at crop maturity by harvesting two rows of soybean in each plot with a small plot combine. Grain moisture content and weight were recorded; grain yield was presented in tonnes $\mathrm{ha}^{-1}$ at $13 \%$ grain moisture. 
Table 1. Effect of preplant herbicides alone and in combination with metribuzin on percent visible control, density and dry biomass of glyphosate-resistant marestail and glyphosate-resistant soybean yield at 6 sites in Ontario from 2018-2019 (Study 1).

\begin{tabular}{|c|c|c|c|c|c|c|}
\hline \multirow[b]{2}{*}{ Herbicide treatment ${ }^{\mathrm{a}}$} & \multirow{3}{*}{$\begin{array}{c}\text { Rate } \\
\left(\mathrm{g} \text { ai/ae ha }{ }^{-1}\right)\end{array}$} & \multicolumn{2}{|c|}{ GR marestail control } & \multirow{3}{*}{$\begin{array}{c}\text { GR marestail } \\
\text { density } \\
\left(\text { plants } \mathrm{m}^{-1} \text { ) }\right.\end{array}$} & \multirow{3}{*}{$\begin{array}{c}\text { GR marestail } \\
\text { dry biomass } \\
\left(\mathrm{g} \cdot \mathrm{m}^{-1}\right)\end{array}$} & \multirow{3}{*}{$\begin{array}{c}\text { Soybean } \\
\text { yield } \\
\left(\mathrm{T} \cdot \mathrm{ha}^{-1}\right)\end{array}$} \\
\hline & & $4 \mathrm{WAT}$ & $8 \mathrm{WAT}$ & & & \\
\hline & & $(\%)$ & $(\%)$ & & & \\
\hline Weed-free control & & 100 & 100 & $0 a$ & $0 a$ & $2.70 a$ \\
\hline Untreated control & & $0 c$ & $0 d$ & $626 d$ & $206.2 d$ & $1.09 \mathrm{~b}$ \\
\hline Saflufenacil ${ }^{\mathrm{b}}$ & 25 & $93 a$ & $93 a b$ & $4 a b$ & $4.7 b$ & $2.51 a$ \\
\hline Saflufenacil + metribuzin $^{\mathrm{b}}$ & $25+400$ & $99 a$ & $98 a$ & $1 a$ & $0.3 a$ & $2.67 a$ \\
\hline 2,4-D ester & 500 & $62 b$ & $58 c$ & $120 c$ & $57.9 c$ & $2.34 a$ \\
\hline 2,4-D ester + metribuzin & $500+400$ & $93 a$ & $91 b$ & $8 b$ & $9.5 b$ & $2.68 a$ \\
\hline Pyraflufen/2,4-D & 532 & $63 b$ & $60 c$ & $146 c$ & $81.5 c$ & $2.22 a$ \\
\hline Pyraflufen/2,4-D + metribuzin & $532+400$ & $96 a$ & $95 a b$ & $3 a b$ & $2.1 a b$ & $2.63 a$ \\
\hline 2,4-D choline/glyphosate & 1720 & $70 \mathrm{~b}$ & $67 c$ & $70 c$ & $44.6 c$ & $2.21 a$ \\
\hline 2,4-D choline/glyphosate + metribuzin + chlorimuron-ethyl & $1720+400+9$ & $96 a$ & $94 a b$ & $2 a b$ & $1.4 a b$ & $2.44 a$ \\
\hline Halauxifen-methyl ${ }^{\mathrm{c}}$ & 5 & $72 b$ & $71 c$ & $120 c$ & $47.0 \mathrm{c}$ & $2.46 a$ \\
\hline 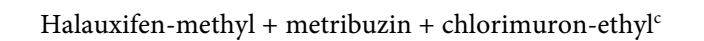 & $5+400+9$ & $94 a$ & $93 a b$ & $6 b$ & $3.8 a b$ & $2.42 a$ \\
\hline
\end{tabular}

Note: Means within a column not sharing a lowercase italic letter differ significantly according to Tukey's HSD at $\mathrm{P}<0.05$. Glyphosate $\left(900 \mathrm{~g}\right.$ ae ha $\left.{ }^{-1}\right)$ added to all treatments except 2,4-D choline/glyphosate treatments. ${ }^{b}$ Included Merge $\left(1 \mathrm{~L} \cdot h \mathrm{~h}^{-1}\right) .{ }^{\mathrm{c}}$ Included MSO concentrate $(1 \% \mathrm{v} / \mathrm{v})$.

Table 2. Influence of dicamba-based preplant herbicides alone and in combination with metribuzin or saflufenacil on percent visible control, density and dry biomass of glyphosate-resistant marestail and glyphosate/dicamba-resistant soybean yield at 6 sites in Ontario from 2018-2019 (Study 2).

\begin{tabular}{|c|c|c|c|c|c|c|}
\hline \multirow[b]{2}{*}{ Herbicide treatment ${ }^{\mathrm{a}}$} & \multirow[b]{2}{*}{ Rate } & \multicolumn{2}{|c|}{ GR marestail control } & \multirow{2}{*}{$\begin{array}{c}\text { GR marestail } \\
\text { density }\end{array}$} & \multirow{2}{*}{$\begin{array}{l}\text { GR marestail } \\
\text { dry biomass }\end{array}$} & \multirow{2}{*}{$\begin{array}{c}\text { Soybean } \\
\text { yield }\end{array}$} \\
\hline & & $4 \mathrm{WAT}$ & $8 \mathrm{WAT}$ & & & \\
\hline & $\left(\mathrm{g} \mathrm{ai} / \mathrm{ae} \mathrm{ha}{ }^{-1}\right)$ & $(\%)$ & $(\%)$ & (plants $\mathrm{m}^{-1}$ ) & $\left(\mathrm{g} \cdot \mathrm{m}^{-1}\right)$ & $\left(\mathrm{T} \cdot \mathrm{ha}^{-1}\right)$ \\
\hline Weed-free control & & 100 & 100 & $0 a$ & $0 a$ & $2.54 a$ \\
\hline Untreated control & & $0 c$ & $0 c$ & $488 d$ & $165.1 d$ & $1.18 b$ \\
\hline Glyphosate/dicamba & 1800 & $79 b$ & $89 a b$ & $7 b c$ & $2.3 b c$ & $2.51 a$ \\
\hline Glyphosate/dicamba + metribuzin & $1800+400$ & $83 b$ & $86 b$ & $21 c$ & $4.7 c$ & $2.65 a$ \\
\hline Glyphosate/dicamba + saflufenacil ${ }^{\text {b }}$ & $1800+25$ & $99 a$ & $97 a$ & $1 a b$ & $0.2 a b$ & $2.45 a$ \\
\hline$S$-metolachlor/dicamba & 1680 & $77 b$ & $83 b$ & $24 c$ & $7.3 b c$ & $2.51 a$ \\
\hline$S$-metolachlor/dicamba + saflufenacil $^{\text {b }}$ & $1680+25$ & $99 a$ & $97 a$ & $1 a b$ & $0.2 a b$ & $2.69 a$ \\
\hline
\end{tabular}

Note: Means within a column not sharing a lowercase italic letter differ significantly according to Tukey's HSD at $\mathrm{P}<0.05$. $^{\text {a }}$ Glyphosate $\left(900\right.$ g ae ha $\left.{ }^{-1}\right)$ added to all treatments except glyphosate/dicamba treatments. ${ }^{\mathrm{b}}$ Included Merge $\left(1 \mathrm{~L} \cdot \mathrm{ha}^{-1}\right)$.

Proc GLIMMIX (SAS Ver. 9.4, SAS Institute Inc., Cary, NC) was utilized to complete the analysis of the data. For each study, the model fixed effect was herbicide treatment. Environments (site-years) chosen for trial placement were selected from a larger target population of growers' fields in Ontario which have 
GR marestail and can reasonably be expected to represent the target population. As a result, environment, replicate within environment and the environment by treatment interaction were designated as random model effects, used as the error term in the analysis. This choice, along with pooling all six environments, allows broad-sense inference in which hypothesis tests and comparisons of treatments are applicable to the entire population represented by the random effects [13] [14]. In this way, the most consistently effective treatments for controlling GR marestail in identity-preserved and glyphosate-resistant or glyphosate/dicamba-resistant soybean under Ontario growing conditions can be identified. Residual and normal probability plots, the Shapiro-Wilk statistic and Pearson chi-square/df were checked to ensure the assumptions of the analysis were met and the best distribution was chosen for each variable. For Study 1, percent visible control ratings of GR marestail were arcsine square-root transformed prior to analysis with the Gaussian distribution. Percent visible control ratings of GR marestail in Study 2, as well as soybean yield for both studies, were analyzed using the Gaussian distribution, without any transformation. Density and dry biomass of GR marestail, as well as soybean seed moisture at harvest, were analyzed using the lognormal distribution for both studies. In instances where the untreated or weed-free controls were assigned a value (either 0 or 100), those treatments were excluded from the analysis. However, treatment means could still be independently compared to the value zero by using the $\mathrm{P}$ value included in the LSMEAN output. Tukey's adjustment was applied to pairwise comparisons prior to determining treatment differences $(P<0.05)$. Treatment means transformed for analysis were back-transformed for presentation of results.

\section{Results and Discussion}

\subsection{Study 1: Control of GR Marestail in Identity-Preserved and Glyphosate-Resistant Soybean}

At 4 and 8 WAA, there was no significant injury in soybean with treatments evaluated at all site-years (data not presented).

At 4 and 8 WAA, glyphosate + saflufenacil, glyphosate + 2,4-D ester, glyphosate + pyraflufen/2,4-D, 2,4-D choline/glyphosate, and glyphosate + halauxifen-methyl, applied PP, controlled GR marestail up to $93 \%, 62 \%, 63 \%, 70 \%$ and $72 \%$, respectively (Table 1 ). Tankmixes of aforementioned herbicide tankmixes/premixes with metribuzin generally improved GR marestail control ( $\mathrm{Ta}$ ble 1). The addition of metribuzin to the tankmixes of glyphosate with saflufenacil, 2,4-D ester and pyraflufen/2,4-D applied PP increased the control to $99 \%$, $93 \%$ and $96 \%$, respectively (Table 1 ). The addition of metribuzin + chlorimuron-ethyl to 2,4-D choline/glyphosate or glyphosate + halauxifen-methyl, applied PP, increased GR marestail control to $96 \%$ and $94 \%$, respectively (Table 1).

Other studies have found that glyphosate + saflufenacil, saflufenacil dimethenamid- $P$, saflufenacil/imazethapyr, 2,4-D ester, metribuzin, or chlorimuron-ethyl + 
metribuzin provide $70 \%, 77 \%, 68 \%, 61 \%, 91 \%$, and $61 \%$ control of GR marestail, respectively [15]. Budd et al. (2016) [10] reported 88\% - 96\% control of GR marestail with glyphosate + saflufenacil applied PP in soybean. Similarly, glyphosate + saflufenacil + 2,4-D-ester controlled GR marestail 95\% - 99\% in soybean [10]. Waggoner et al. (2011) [16] also reported 96\% control of GR marestail at $1 \mathrm{WAA}$ and $65 \%$ control of GR marestail at 4 WAA with a PP application of saflufenacil in soybean. Kruger et al. (2010) [17] reported as much as $97 \%$ control of GR marestail with 2,4-D ester in soybean. Tardif and Smith (2003) [18] found only $73 \%$ control of marestail with metribuzin but Byker et al. (2013) found as much as $99 \%$ control of GR marestail with glyphosate + metribuzin applied PP in soybean. Moseley and Hagood (1990) [19] reported 90\% control of marestail with a PP application chlorimuron-ethyl + metribuzin, however the control was only 78\% with metribuzin alone. Zimmer et al. (2018) [20] observed as much as $90 \%$ GR marestail control with halauxifen-methyl alone and $75 \%$, $98 \%$ and $89 \%$ GR marestail control with halauxifen-methyl + chlorimuron-ethyl tankmixed with flumioxazin, saflufenacil or dicamba, respectively. McCauley et al. (2018) [21] [22] found 80\% GR marestail control with halauxifen-methyl which is similar to the findings in this study.

There was a high GR marestail pressure at this site with an average of $626 \mathrm{GR}$ marestail plants $\mathrm{m}^{-2}$ at $8 \mathrm{WAA}$ (Table 1). At $8 \mathrm{WAA}$, glyphosate + saflufenacil, glyphosate + 2,4-D ester, glyphosate + pyraflufen/2,4-D, 2,4-D choline/glyphosate, and glyphosate + halauxifen-methyl, applied PP, reduced GR marestail density $99 \%, 81 \%, 77 \%, 89 \%$ and $81 \%$, respectively (Table 1). The addition of metribuzin to the tankmixes of glyphosate with saflufenacil, 2,4-D ester and pyraflufen/2,4-D, applied PP, reduced GR marestail density 99\% - 100\% (Table 1). The addition of metribuzin + chlorimuron-ethyl to 2,4-D choline/glyphosate or glyphosate + halauxifen-methyl, applied PP, reduced the GR marestail density $100 \%$ and $99 \%$, respectively (Table 1 ). Other research has reported a density reduction of $78 \%-86 \%$ with saflufenacil, applied PP, in soybean [6]. The addition of amitrole to the tankmix decreased GR marestail density $99 \%$ compared to the weedy control [6]. Budd et al. (2016) [10] reported a 96\% reduction in density of GR marestail with glyphosate + saflufenacil at 8 WAA. Eubank et al. (2008) [22] reported only 66\% reduction in density of GR marestail with glyphosate + metribuzin applied PP in soybean. Zimmer et al. (2018) [20] [23] reported $96 \%, 76 \%, 91 \%$ and $71 \%$ reduction in density of GR marestail with saflufenacil, halauxifen-methyl, halauxifen-methyl + chlorimuron-ethyl + flumioxazin and dicamba, respectively.

At 8 WAA, glyphosate + saflufenacil, glyphosate $+2,4$-D ester, glyphosate + pyraflufen/2,4-D, 2,4-D choline/glyphosate and glyphosate + halauxifen-methyl, applied PP, reduced GR marestail biomass $98 \%, 72 \%, 60 \%, 78 \%$ and $77 \%$, respectively (Table 1). The addition of metribuzin to the tankmixes of glyphosate with saflufenacil, 2,4-D ester and pyraflufen/2,4-D reduced GR marestail biomass $95 \%-100 \%$ (Table 1). The addition of metribuzin + chlorimuron-ethyl to 
2,4-D choline/glyphosate and glyphosate + halauxifen-methyl reduced biomass of GR marestail $99 \%$ and $98 \%$, respectively (Table 1).

GR marestail interference reduced soybean yield $60 \%$ in this study. Reduced GR marestail interference with all the herbicide treatments evaluated resulted in soybean yield that was similar to the weed-free control. Other research has reported that GR marestail interference reduced soybean yield 73\% [10].

\subsection{Study 2. Control of GR Marestail in Glyphosate/Dicamba-Resistant Soybean}

At 4 and 8 WAA, there was no significant injury in soybean with treatments evaluated at all site-years (data not presented).

At 4 and 8 WAA, glyphosate/dicamba, applied PP, controlled GR marestail $79 \%-89 \%$ in glyphosate/dicamba-resistant soybean (Table 2). The addition of metribuzin or saflufenacil to the above premix provided $83 \%-86 \%$ and $97 \%$ 99\% GR marestail control, respectively (Table 2). At 4 and 8 WAA, glyphosate + $S$-metolachlor/dicamba controlled GR marestail 77\% - 83\% (Table 2). The addition of metribuzin or saflufenacil to the above tankmix controlled GR marestail $83 \%-87 \%$ and $97 \%$ - 99\%, respectively. Generally, there was a significant improvement of GR marestail control with the addition of saflufenacil to glyphosate/dicamba or glyphosate $+S$-metolachlor/dicamba (Table 2). However, there was no improvement of GR marestail control with the addition of metribuzin to glyphosate/dicamba or glyphosate $+S$-metolachlor/dicamba (Table 2 ).

There was excellent GR marestail pressure in this study with an average of 488 GR marestail plants $\mathrm{m}^{-2}$ at $8 \mathrm{WAA}$ (Table 2). At 8 WAA, glyphosate/dicamba, applied PP, reduced GR marestail density and biomass $99 \%$. The addition of metribuzin or saflufenacil to the above premix did not result in a further decrease in GR marestail density or biomass (Table 2). At 8 WAA, glyphosate + $S$-metolachlor/dicamba, applied PP, reduced GR marestail density $95 \%$. The addition of saflufenacil to glyphosate $+S$-metolachlor/dicamba, applied PP, reduced GR marestail density $100 \%$, but there was no significant decrease in GR marestail density with the addition of metribuzin. At 8 WAA, glyphosate + $S$-metolachlor/dicamba, applied PP, reduced GR marestail biomass $96 \%$. The addition of metribuzin or saflufenacil to glyphosate $+S$-metolachlor/dicamba, applied PP, did not result in a further decrease in GR marestail biomass.

Hedges et al. (2019) [24] reported only 87\% GR marestail control with glyphosate/dicamba at $8 \mathrm{WAA}$ in glyphosate/dicamba-resistant soybean. However, there was $97 \%, 96 \%, 97 \%$, and $98 \%$ GR marestail control with glyphosate/dicamba tankmixes with saflufenacil, saflufenacil/dimethenamid-P, saflufenacil/imazethapyr, or paraquat at $8 \mathrm{WAA}$ in glyphosate/dicamba-resistant soybean [24]. Glyphosate/dicamba + metribuzin controlled GR marestail 92\%, which was similar to metribuzin applied alone [15].

GR marestail interference reduced soybean yield 53\% in glyphosate/ dicamba-resistant soybean (Table 2). Reduced GR marestail interference with all the herbicide treatments evaluated resulted in soybean yield that was similar to 
the weed-free control (Table 2). Results are comparable to Hedges et al. (2019) [24] who reported $67 \%$ soybean yield reduction due to GR marestail interference in glyphosate/dicamba-resistant soybean. Eubank et al. (2008) [22] reported up to a $97 \%$ reduction in soybean yield due to GR marestail interference. However, Byker et al. (2013) [11] reported a $35 \%$ to $42 \%$ reduction in soybean yield due to GR marestail interference in soybean.

\section{Conclusions}

Results from Study 1 conclude that glyphosate + 2,4-D ester, glyphosate + pyraflufen/2,4-D, 2,4-D choline/glyphosate or glyphosate + halauxifen-methyl, applied PP, do not provide adequate control of GR marestail in identity-preserved or glyphosate-resistant soybean. The addition of metribuzin to these herbicides improved GR marestail control significantly. Glyphosate in a tankmix with saflufenacil, saflufenacil + metribuzin, 2,4-D ester + metribuzin, pyraflufen/2,4-D + metribuzin, 2,4-D choline/glyphosate + metribuzin + chorimuron or halauxifenmethyl + metribuzin + chlorimuron-ethyl, applied PP at the rates evaluated, provided $>91 \%$ GR marestail control in identity-preserved and glyphosate-resistant soybean.

In glyphosate/dicamba-resistant soybean, generally there was a significant improvement of GR marestail control with the addition of saflufenacil to glyphosate/dicamba or $S$-metolachlor/dicamba. In contrast, there was no significant improvement of GR marestail control with the addition of metribuzin to glyphosate/dicamba or glyphosate $+S$-metolachlor/dicamba. Glyphosate/dicamba + saflufenacil and glyphosate $+S$-metolachlor/dicamba + saflufenacil, applied PP, provided consistent season-long control ( $\geq 97 \%)$ of GR marestail. Glyphosate/dicamba, glyphosate/dicamba + metribuzin, glyphosate $+S$-metolachlor/dicamba or glyphosate $+S$-metolachlor/dicamba + metribuzin did not provide consistent control of GR marestail in glyphosate/dicamba-resistant soybean.

Reduced GR marestail interference with all the herbicide treatments evaluated resulted in soybean yield that was similar to the weed-free control in conventional/glyphosate- and glyphosate/dicamba-resistant soybean.

\section{Acknowledgements}

Funding for this project was provided in part by the Grain Farmers of Ontario (GFO).

\section{Conflicts of Interest}

The authors declare no conflicts of interest regarding the publication of this paper.

\section{References}

[1] Weaver, S.E. (2001) The Biology of Canadian Weeds. 115. Conyza canadensis. Canadian Journal of Plant Science, 81, 867-875. https://doi.org/10.4141/P00-196 
[2] Loux, M.M., Stachler, J., Johnson, B., Nice, G., Davis, V. and Nordby, D (2006) Biology and Management of Horseweed. Purdue University Extension, West Lafayette. https://www.extension.purdue.edu/extmedia/gwc/gwc-9-w.pdf

[3] Buhler, D.D. and Owen, M.D. (1997) Emergence and Survival of Horseweed (Conyza canadensis). Weed Science, 45, 98-101. https://doi.org/10.1017/S0043174500092535

[4] Smisek, A. (1995) Resistance to Paraquat in Erigeron canadensis L. M.Sc. Thesis, University of Western Ontario, London, ON.

[5] Tozzi, E. and Van Acker, R.C. (2014) Effects of Seedling Emergence Timing on the Population Dynamics of Horseweed (Conyza canadensis var. canadensis). Weed Science, 62, 451-456. https://doi.org/10.1614/WS-D-13-00150.1

[6] Davis, V.M. and Johnson, W.G. (2008) Glyphosate-Resistant Horseweed (Conyza canadensis) Emergence, Survival, and Fecundity in No-Till Soybean. Weed Science, 56, 231-236. https://doi.org/10.1614/WS-07-093.1

[7] Royer, F. and Dickinson, R. (1999) Weeds of Canada and the Northern United States: A Guide for Identification. University of Alberta.

[8] Shields, E.J., Dauer, J.T., VanGessel, M.J. and Neumann, G. (2006) Horseweed (Conyza canadensis) Seed Collected in the Planetary Boundary Layer. Weed Science, 54, 1063-1067. https://doi.org/10.1614/WS-06-097R1.1

[9] Budd, C.M., Soltani, N., Robinson, D.E., Hooker, D.C., Miller, R.T. and Sikkema, P.H. (2016) Improving the Consistency of Glyphosate-Resistant Canada Fleabane (Conyza canadensis) Control with Saflufenacil: Distribution and Control in Soybean (Glycine max). M.Sc. Thesis, University of Guelph, Guelph, 51 p.

[10] Budd, C.M., Soltani, N., Robinson, D.E., Hooker, D.C., Miller, R.T. and Sikkema, P.H. (2016) Control of Glyphosate Resistant Canada Fleabane with Saflufenacil plus Tankmix Partners in Soybean. Canadian Journal of Plant Science, 96, 989-994. https://doi.org/10.1139/cjps-2015-0332

[11] Byker, H.P., Soltani, N., Robinson, D.E., Tardif, F.J., Lawton, M.B. and Sikkema, P.H. (2013) Control of Glyphosate-Resistant Horseweed (Conyza canadensis) with Dicamba Applied Preplant and Postemergence in Dicamba-Resistant Soybean. Weed Technology, 27, 492-496. https://doi.org/10.1614/WT-D-13-00023.1

[12] Sikkema, P.H. and Soltani, N. (2020) Control of Glyphosate-Resistant Canada Fleabane with Three-Way Tankmixes in Soybean. Weed Science Society of America Abstract, 60, 345.

[13] Moore, K.J. and Dixon, P.M. (2015) Analysis of Combined Experiments Revisited. Agronomy Journal, 107, 763-771. https://doi.org/10.2134/agronj13.0485

[14] Stroup, W.W. (2013) Generalized Linear Mixed Models. CRC Press, Boca Raton.

[15] Soltani, N., Brown, L.R., and Sikkema, P.H. (2017) Control of Glyphosate-Resistant Canada Fleabane in Soybean with Preplant Herbicides. Canadian Journal of Plant Science, 97, 408-410. https://doi.org/10.1139/CJPS-2016-0299

[16] Waggoner, B.S., Mueller, T.C., Bond, J.A. and Steckel, L.E. (2011) Control of Glyphosate-Resistant Horseweed (Conyza canadensis) with Saflufenacil Tank Mixtures in No-Till Cotton. Weed Technology, 25, 310-315. https://doi.org/10.1614/WT-D-10-00161.1

[17] Kruger, G.R., Davis, V.M., Weller, S.C. and Johnson, W.G. (2010) Control of Horseweed (Conyza canadensis) with Growth Regulator Herbicides. Weed Technology, 24, 425-429. https://doi.org/10.1614/WT-D-10-00022.1

[18] Tardif, F. and Smith, P. (2003) Alternative Herbicides for the Control of Canada 
Fleabane in Soybeans. Crop Advances: Field Crop Reports (Interim Report). http://www.ontariosoilcrop.org/wp-content/uploads/2015/07/V1Soy7.pdf

[19] Moseley, C.M. and Hagood, E.S. (1990) Horseweed (Conyza canadensis) Control in Full-Season No-Till Soybeans (Glycine max). Weed Technology, 4, 814-818. https://doi.org/10.1017/S0890037X00026452

[20] Zimmer, M., Young, B.G. and Johnson, W.G. (2018) Weed Control with Halauxifen-Methyl Applied Alone and in Mixtures with 2,4-D, Dicamba and Glyphosate. Weed Technology, 32, 597-602. https://doi.org/10.1017/wet.2018.48

[21] McCauley, C.L., Johnsome, W.G. and Young, B.G. (2018) Efficacy of Halauxifen-Methyl on Glyphosate-Resistant Horseweed (Erigeron canadensis). Weed Science, 66, 758-763. https://doi.org/10.1017/wsc.2018.43

[22] Eubank, T.W., Poston, D.H., Nandula, V.K., Koger, C.H., Shaw, D.R. and Reynolds, D.B. (2008) Glyphosate-Resistant Horseweed (Conyza canadensis) Control Using Glyphosate-, Paraquat-, and Glufosinate-Based Herbicide Programs. Weed Technology, 22, 16-21. https://doi.org/10.1614/WT-07-038.1

[23] Zimmer, M., Young, B.G. and Johnson, W.G. (2018) Herbicide Programs Utilizing Halauxifen-Methyl for Glyphosate-Resistant Horseweed (Conyza canadensis) Control in Soybean. Weed Technology, 32, 659-664. https://doi.org/10.1017/wet.2018.60

[24] Hedges, B.K., Soltani, N., Robinson, D.E., Hooker, D.C. and Sikkema, P.H. (2019) Control of Glyphosate-Resistant Canada Fleabane in Ontario with Multiple Effective Modes-of-Action in Glyphosate/Dicamba-Resistant Soybean. Canadian Journal of Plant Science, 99, 78-83. https://doi.org/10.1139/cjps-2018-0067 